\title{
PENGEMBANGAN WAWASAN \\ WARGA SEKOLAH LABORATORIUM UNDIKSHA TENTANG SEKOLAH BERWAWASAN LINGKUNGAN DAN MITIGASI BENCANA (SWALIBA)
}

\author{
Ida Bagus Made Astawa1, I Gede Budiarta², I Wayan Treman², I Made Sarmita ${ }^{4}$ \\ 1,2,3,4 Jurusan Geografi, Universitas Pendidikan Ganesha \\ email: md.astawa@undiksha.ac.id
}

\begin{abstract}
Abstrak
Pelestarian lingkungan dalam rangka global warming dan geologis Indonesia yang berada pada kawasan Pacific Ring of Fire merupakan landasan yang digunakan untuk mencanangkan Program Sekolah Berwawasan Lingkungan dan Mitigasi Bencana (SWALIBA) di Indonesia sebagai bentuk pendidikan karakter, terutama pada sekolah-sekolah yang berada pada kawasan rawan bencana. Program ini bertujuan untuk menciptakan generasi muda yang berkarakter cinta dan peduli terhadap lingkungan dan memahami bagaimana sikap tanggap terhadap bencana. Sekolah Lab. Undiksha secara geologi berada pada kawasan Patahan Seririt yang sangat labil sehingga rawan bencana gempa dan tsunami. Berkenaan dengan itu, dilakukan Pengabdian kepada Masyarakat $(\mathrm{PkM})$ dengan salah satu kegiatannya adalah memberikan wawasan SWALIBA kepada warga Sekolah Lab. Undiksha. Pemberian wawasan menggunakan metode Pendidikan dengan tiga tahapan (pemberian materi, diskusi, dan evaluasi) yang dilakukan secara daring melalui webinar. Hasil pengabdian yang dilakukan menunjukkan bahwa wawasan SWALIBA warga Sekolah Lab. Undiksha tergolong 'baik' (Mean $=74,73)$. Sebagai langkah awal untuk mengembangkan Program SWALIBA di Sekolah Lab. Undiksha, wawasan yang tergolong baik ini sangat dibutuhkan, karena akan dapat memberikan kontribusi pada pengembangan program yang akan dirancang.
\end{abstract}

Kata Kunci:Wawasan SWALIBA, Warga Sekolah Lab. Undiksha, rawan bencana.

\begin{abstract}
Environmental conservation in the context of global warming and Indonesia's geology located in the Pacific Ring of Fire area is the basis used to launch the Environmentally Insight School and Disaster Mitigation Program (SWALIBA) in Indonesia as a form of character education, especially in schools located in vulnerable areas. disaster. This program aims to create a young generation with character of love and care for the environment and understand how to respond to disasters. The Undiksha Laboratory School is geologically located in the Seririt Fault area which is very unstable so it is prone to earthquakes and tsunamis. In this regard, Community Service (PkM) is carried out with one of the activities being to provide SWALIBA insight to the residents of the Undiksha Laboratory School (Managers, Directors, Teachers, and Employees). Providing insight using the Education method with three stages (providing material, discussion, and evaluation) which is carried out online through webinars. The results of the service carried out showed that the SWALIBA insight of the Undiksha Laboratory School residents was classified as 'good' (Mean $=74.73$ ). As a first step to developing the SWALIBA Program at the Undiksha Laboratory School, this good insight is needed, because it will be able to contribute to the development of the program to be designed.
\end{abstract}

Keywords:SWALIBA insight, Undiksha Laboratory School residents, disaster prone. 


\section{PENDAHULUAN}

Salah satu penyebab dari global warming (fenomena meningkatnya suhu rata-rata atmosfer, daratan bumi, lautan secara menyeluruh) adalah keberadaan hutan sebagai paru-paru dunia yang semakin berkurang. Indonesia merupakan salah satu negara dengan areal hutan terluas di dunia dan otomatis karena hal itu juga Indonesia menjadi salah satu negara penyedia oksigen alami terbesar di dunia sehingga dijuluki sebagai paruparu dunia. Luas areal hutan Indonesia berdasarkan data Kemeterian Lingkungan Hidup dan Kehutanan (KLHK) tahun 2015 mencapai 128 juta Ha. Namun sayang setiap tahunnya luasan ini terus berkurang. Hal ini tidak lain penyebabnya adalah maraknya kebakaran hutan yang terjadi, penebangan hutan secara ilegal untuk kebutuhan industri maupun bisnis, dan degradasi luas hutan karena terjadinya alih fungsi hutan.

Berkenaan dengan itu, dalam rangka pembangunan karakter siswa yang berwawasan lingkungan dicanangkan 'Program Adiwiyata' oleh Kementerian Negara Lingkungan Hidup pada tahun 2006. Program ini merupakan tindak lanjut dari MoU yang ditanda tangani pada tanggal 3 Juni 2005 antara Menteri Negara Lingkungan Hidup dan Menteri Pendidikan Nasional (MNLH dan Kemendiknas: 2006). Tujuan umum dari Program Adiwiyata ini adalah untuk membentuk sekolah peduli dan berbudaya lingkungan yang mampu berpartisipasi dan melaksanakan upaya pelestarian lingkungan dan pembangunan berkelanjutan bagi kepentingan generasi sekarang maupun yang akan datang. Berkenaan dengan itu, Program Adiwiyata harus berlandaskan pada norma-norma kebersamaan, keterbukaan, kejujuran, keadilan, dan kelestarian fungsi lingkungan hidup dan Sumber Daya Alam. Tujuan tersebut menunjukan bahwa Program Adiwiyata merupakan Pendidikan Karakter dalam rangka membentuk perilaku (pengetahuan, sikap, dan tindakan) siswa yang berwawasan lingkungan.

Pada sisi lain, Indonesia secara geologi merupakan negara yang berada pada kawasan Cincin Api Pasific (Pacific Ring of Fire) sehingga setiap saat berpotensi besar mengalami bencana alam. Hal ini disebabkan letak geologisnya yang berada di antara gugus gunung api dan titik pertemuan tiga lempeng bumi (lempeng Pacifik, lempeng Asia, dan lempeng Australia) yang rawan terhadap bencana alam. Pada 2018 banyak bencana alam yang menerpa Indonesia. Di antaranya yang masih membekas di ingatan adalah tsunami di Palu dan Donggala sekitar bulan Oktober 2018 dan tsunami Selat Sunda yang terjadi di wilayah Banten, khususnya Anyer, Tanjung Lesung, Carita, dan sekitarnya pada bulan Desember 2018. Sebelumnya, pada tanggal 26 Desember 2014 gempa bumi yang disertai dengan tsunami terbesar di Indonesia terjadi di Nanggroe Aceh Darussalam (NAD), tepatnya di Banda Aceh. Gempa bumi tersebut berkekuatan atau bermagnitudo 9,1 hingga 9,2 dari dasar laut sebelah Barat Aceh, yang setelah itu diikuti tsunami sehingga meluluh lantakkan daerah Banda Aceh dan sekitarnya.

Menyadari akan hal tersebut, penanaman karakter dengan nilai-nilai yang berwawasan lingkungan dan mitigasi bencana kepada generasi muda sebagai generasi penerus menjadi sesuatu yang sangat penting. Salah satu upaya yang dapat dilakukan adalah melalui pendidikan formal dengan mengkemasnya dalam bingkai pendidikan karakter. Kusuma (2012:5) mengemukakan pendidikan karakter adalah sebuah proses transformasi nilai-nilai kehidupan untuk ditumbuhkembangkan dalam kepribadian seseorang sehingga menjadi satu dalam perilaku kehidupan orang tersebut. Pendidikan karakter bukan hanya berurusan dengan penanaman nilai pada diri peserta didik, melainkan merupakan sebuah usaha 
bersama untuk menciptakan sebuah lingkungan pendidikan tempat setiap individu dapat menghayati kebebasannya sebagai sebuah prasyarat bagi kehidupan moral yang dewasa. Pendidikan karakter bertujuan untuk meningkatkan mutu penyelenggaraan dan hasil pendidikan yang mengarah pada pencapaian pembentukan karakter dan etika mulia siswa secara utuh terpadu dan berimbang sesuai standar kompetensi lulusan (Mahbubi, 2012: 42). Melalui pendidikan karakter diharapkan peserta didik mampu secara mandiri meningkatkan pengetahuannya terhadap karakter baik, dapat mengolah rasa serta mempraktikkan pengetahuan yang dimiliki dalam kehidupan seharihari.

Sekolah Berawasan Lingkungan dan Mitigasi Bencana (SWALIBA) sebagai pengejawatahan dari UU No. 24 Tahun 2007 tentang penanggulangan bencana dan Peraturan Pemerintah No. 21 tahun 2008 tentang penyelenggaraan penanggulangan bencana dan penyempurnaan program Adiwiyata, merupakan Pendidikan karakter. Pada hakikatnya SWALIBA ini dicanangkan tidak saja dalam rangka menciptakan generasi muda yang berkarakter cinta dan peduli terhadap lingkungan namun juga karakter yang memahami bagaimana sikap tanggap terhadap bencana. Program ini erat kaitannya dengan upaya meningkatkan kualitas sumber daya manusia melalui penanaman budaya yang tidak saja berwawasan lingkungan, tetapi juga memiliki pemahaman terhadap mitigasi bencana. SWALIBA merupakan program yang dicanangkan sekolah sebagai salah satu bentuk peningkatan mutu pendidikan dalam lingkungan sekolah melalui Pendidikan karakter, terutama pada sekolah-sekolah yang berada pada Kawasan rawan bencana.

Sekolah Laboratorium Undiksha Singaraja (Sekolah Lab. Undiksha) merupakan salah satu swasta yang berada di Kabupaten Buleleng memiliki potensi gempa bumi dan tsunami. Hal tersebut disebabkan sejumlah wilayah di Kabupaten Buleleng terletak di atas lempeng bumi yang dapat bergeser kapan saja. Salah satu lempeng yang sangat rentan adalah lempeng Seririt. Intensitas potesi gempa bumi di utara Pulau Bali ini lebih tinggi dibandingkan Bali Selatan karena dipengaruhi oleh sesar naik Flores yang membujur di utara pulau Bali hingga Nusa Tenggara. Hal tersebut dipaparkan secara jelas dalam webinar Ikatan Ahli Geologi Indonesia Pengurus Daerah (IAGIPengda) Bali, Jumat (12/6/2020) yang dipandu Ketua IAGI Pengda Bali, Ketut Arinata dengan menghadirkan dua narasumber, yakni Kepala Bidang Mitigasi Gempabumi dan Tsunami Badan Meteorologi Klimatologi dan Geofisika (BMKG) dan Putu Ary Wijaya, Bali Geoscience Research Group IAGI Pengda Bali. Fenomena kerawanan bencana ini juga diperkuat dengan data yang diperoleh dari BMKG yang menyatakan bahwa di bawah Pulau Bali terdapat zone gempa bumi berupa slab atau patahan dengan kedalaman $100 \mathrm{Km}$ dan kemiringan mencapai $65^{\circ}$ dengan jangkauan sampai $650 \mathrm{Km}$ di bawah bagian utara Bali. Patahan yang cukup rawan di Buleleng adalah tiga patahan, yaitu Patahan Seririt, Patahan Banyuwedang, dan Patahan Tejakula (Bali Post, 2017).

Lokasi Sekolah Lab. Udiksha sangat dekat dengan Laut Bali yang merupakan satu kawasan yang terletak di atas lempeng Seririt). Hal ini menunjukkan bahwa Sekolah Lab. Undiksha berada pada Kawasan rawan bencana, yaitu gempa dan tsunami. Lokasi tersebut menyebabkan Sekolah Lab. Undiksha Singaraja juga harus memiliki program kesiapan bencana atau yang disebut dengan mitigasi bencana. Selain itu, Sekolah Lab. Undiksha Singaraja berkenaan dengan lingkungan hidup, memiliki kawasan hijau yang cukup luas dengan tanaman dari semak sampai dengan pohonpohon berkayu besar. Namun demikian, dalam pemeliharaannya tidak melibatkan siswa secara terprogram. Pengelolaan kebersihan sekolah juga dilakukan sepenuhnya oleh pihak 
sekolah. Pengembangan karakter berwawasan lingkungan yang dilakukan secara terprogram pada pembelajaran juga masih belum ada. Hal ini menunjukkan bahwa pemberdayaan peran kelembagaan dan kemampuan komunitas sekolah belum dioptimalisasi berkenaan dengan lingkungan dan kebencanaan.

Selain itu, pengintegrasian pengurangan resiko bencana ke dalam kurikulum satuan pendidikan formal baik intra maupun ekstrakurikuler juga secara terprogram belum dilakukan, termasuk juga untuk membangun kemitraan dan jaringan antar berbagai pihak dalam mendukung pelaksanaan pengurangan resiko bencana di sekolah. Belum adanya di Sekolah Lab. Undiksha Singaraja program dalam rangka pembentukan karakter siswa yang berwawasan lingkungan dan mitigasi bencana, tentu akan berimplikasi pada sikap peduli lingkungan siswa dan pemahamannya terhadap mitigasi bencana. Selain itu, yang berkembang sementara ini, pembentukan sikap peduli lingkungan dan kebencanaan dinilai hanya menjadi tanggungjawab sejumlah mata pelajaran, seperti geografi, biologi, dan IPS.

Berpijak pada kondisi eksisting Sekolah Lab. Undiksha sebagaimana telah dikemukakan tersebut dan menyadari SWALIBA sebagai Pendidikan karakter yang mengedepankan keteladanan, pengembangan wawasan para Pengelola (Yayasan, Direksi, Kepala Sekolah, dan KTU), Guru, dan pegawai penting untuk dilakukan terlebih dahulu. Wawasan SWALIBA yang dimiliki diharapkan kemudian dapat diterapkan dalam penyusunan Program SWALIBA di Sekolah Lab. Undiksha untuk kemudian dimplementasikan pada berbagai kegiatan sekolah dalam mengembangkan karakter siswa yang berwawasan lingkungan dan mitigasi bencana.
Berkenaan dengan itu dilakukan kegiatan Pengabdian kepada Masyarakat (PkM) di Sekolah Lab. Undiksha yang salah satu tujuannya adalah memberikan wawasan SWALIBA kepada warga Sekolah Lab. Undiksha, yaitu para Pengelola, Direksi, Guru, dan Pegawai. Pengembangan wawasan SWALIBA warga Sekolah Lab. Undiksha merupakan langka awal untuk mengembangkan karakter siswa Sekolah Lab. Undiksha yang berwawasan lingkungan dan mitigasi bencana.

\section{METODE}

Kegiatan dalam mengembangkan wawasan warga Sekolah Lab. Undiksha pada kegiatan PkM ini menggunakan 'metode pendidikan' yang dikemas dalam bentuk webinar. Pendidikan melalui webinar menggunakan tiga tahapan, yaitu:

(1) Pemberian materi tentang SWALIBA (Rasional Pencanangan SWALIBA, Ruang Lingkup Program SWALIBA, Pengelolaan Program SWALIBA, dan Evaluasi Program SWALIBA),

(2) Sesi tanya-jawab yang difokuskan pada pengembangan Program SWALIBA

(3) Evaluasi wawasan SWALIBA peserta webinar yang dilakukan melalui Googleform. Pertanyaan dalam evaluasi yang dilakukan hanya terdiri dari 10 soal dengan jawaban 'ya/setuju/benar/siap atau tidak/kurang setuju/salah/tidak siap'

Kriteria yang digunakan untuk menganalisis wawasan warga Sekolah Lab. Undiksha tentang SWALIBA adalah kriteria sebagaimana terlihat pada Tabel 1. 
Jurnal Widya Laksana, Vol.11, No.1, Januari 2022

Tabel 1. Kriteria Wawasan tentang Sekolah Berwawasan Lingkungan dan Mitigasi Bencana (SWALIBA)

\begin{tabular}{ccc}
\hline Skor Persentil & Nilai & Kriteria \\
\hline $85-100$ & A & Sangat Baik \\
$70-84$ & B & Baik \\
$55-69$ & C & Cukup \\
$45-54$ & D & Kurang \\
$0-44$ & E & Sangat Kurang \\
\hline
\end{tabular}

\section{HASIL DAN PEMBAHASAN}

Pengembangan wawasan warga Sekolah Lab. Undiksha tentang SWALIBA sebagaimana telah dikemukakan dilakukan dengan Metode Pendidikan yang dikemas dalam bentuk Webinar yang dilakukan secara daring untuk menghindari penyebaran Covid19. Peserta yang diharapkan hadir dalam Webinar adalah warga Seklah Lab. Undiksha yang terdiri dari: (1) Pengelola Sekolah Lab. Undiksha yang terdiri dari Yayasan/3 Orang, Direksi/2 Orang, Kepala Sekolah masing-masing jenjang/4 orang, dan Kepala Tata Usaha/1 orang; (2) Guru (150 orang), dan (3) Pegawai (47 orang). Seluruh peserta webinar yang diharapkan hadir adalah 207 orang.
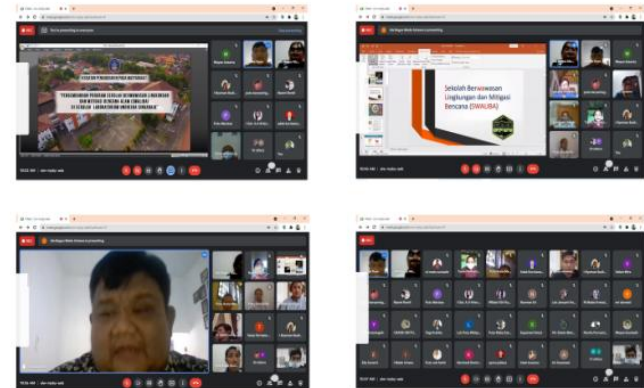

Gambar 1. Kegiatan Sosialisasi

Program SWALIBA

Kegiatan ini berlangsung pada hari Jumat, 13 Agustus 2021 dari Jam $10.00 \mathrm{~s} / \mathrm{d} 13.00$ WITA melalui aplikasi zoom. Pada saat webinar berlangsung tidak semua peserta (207 orang) yang diharapkan dapat hadir. Kehadiran peserta hanya mencapai 166 orang $(80 \%)$ terdiri dari Pengelola 8 orang, Guru 120 orang, dan Pegawai 38 orang. Terdapat tiga alasan utama yang disampaikan berkenaan dengan ketidak hadiran peserta, yaitu: (1) terlibat sebagai panitia Vaksinasi Covid-19 yang dilaksanakan di Sekolah
Lab. Undiksha untuk siswa sekolah swasta pada tanggal tersebut, (2) alasan sakit, dan (3) alasa ijin. Namun demikian, dilihat dari kehadiran peserta webinar yang mencapai $80 \%$ dinilai sudah mewakili warga Sekolah Lab. Undiksha. Tujuan utama dari webinar ini adalah untuk mensosialisasikan SWALIBA sehingga warga Sekolah Lab. Undiksha memiliki wawasan tentang SWALIBA. Hal ini merupakan langkah awal untuk menjadikan Sekolah Lab. Undiksha sebagai SWALIBA yang ke depannya mampu mendidik siswanya memiliki wawasan dan perilaku berwawasan lingkungan dan mitigasi bencana. Terdapat 10 pertanyaan yang dimintakan respon dari peserta webinar melalui googleform.

Sosialisasi tentang SWALIBA kepada warga Sekolah Lab. Undiksha diberikan oleh narasumber Dr. Ida Bagus Made Astawa, M.Si. dari Program Studi Pendidikan Geografi, Jurusan Geografi, FHIS, Undiksha. Materi tentang SWALIBA yang disampaikan mencakup empat materi pokok, yaitu: (1) Rasional Pencanangan SWALIBA, (2) Ruang Lingkup Program SWALIBA, (3) Pengelolaan Program SWALIBA, dan (4) Evaluasi Program SWALIBA disajikan dalam bentuk Power Point. Pemberian materi berlangsung sekitar satu (1) jam tanpa jedah. Setelah penyampaian materi dapat diselesaikan, kegiatan dilanjutkan dengan diskusi.

Pada kegiatan diskusi, permasalahan yang mengemuka pada hakikatnya dapat dipilah menjadi tiga, yaitu: (1) Apa yang harus dilakukan terlebih dahulu untuk mengembangkan program SWALIBA di Sekolah Lab. 
Undiksha?, (2) Pencanangan program SWALIBA di Sekolah Lab. Undiksha, apakah akan merubah kurikulum yang sudah berlaku sekarang (Kurikulum 2013 Edisi Revisi)?, dan (3) Siapa saja yang dilibatkan dalam penyusunan program SWALIBA Sekolah Lab. Undiksha?.

Berkenaan dengan itu, respon diberikan peserta dalam diskusi oleh narasumber kemudian dirangkum yang pada hakikatnya dapat disimpulkan sebagai berikut.

(1) Berkenaan dengan pengembangan program SWALIBA, yang dilakukan terlebih dahulu adalah mengidentifikasi apa yang dibutuhkan untuk pengembangannya, seperti: (1) perencanaan tujuan SWALIBA, (2) perencanaan sumber daya pendukung dan hambatan yang diperkirakan dalam pencapai tujuan, dan (3) penentuan pendekatan yang akan digunakan dalam mencapai tujuan.

(2) Pencanangan Program SWALIBA di Sekolah Lab. Undiksha tidak akan merubah kurikulum yang diimpellemtasikan (Kurikulum 2013 Edisi Revisi). Program SWALIBA yang dikembangkan merupakan suplemen yang dilakukan dalam guru melakukan pengembangan kurikulum, yaitu memasukkannya dalam RPP yang disusun sehingga terimpelemntasi dalam pembelajaran di kelas.
(3) Idealnya yang dilibatkan dalam Penyusunan Program SWALIBA Sekolah Lab. Undiksha adalah segenap warga Sekolah Lab. Undiksha yang dalam hal ini mencakup: Pengelola (Yayasan, Direksi, Kepala Sekolah, dan KTU), Guru, dan Pegawai. Pelibatan segenap warga Sekolah Lab. Undiksha penting dilakukan dalam rangka menjadikan program yang sudah disusun adalah milik bersama sehingga dalam mengorganisasikan, memonitoring, dan mengkoordinasikan program menjadi lebih mudah. Rancangan kegiatan sebagai implementasi dari program yang telah disusun sebaiknya melibatkan siswa, terutama yang berkaitan dengan Pendidikan dan praktik pelestarian lingkungan dan mitigasi bencana.

Hasil evaluasi yang dilakukan menunjukkan bahwa warga Sekolah Lab. Undiksha telah memiliki wawasan tentang SWALIBA. Skor minimal yang diperoleh adalah 50 (terkategori kurang) dan tertinggi 100 (terkategori sangat baik). Berdasarkan hasil pengolahan data yang dilakukan nilai rata-rata yang dicapai tergolong baik $($ Mean $=74,73)$. Secara lebih jelas sebaran skor yang diperoleh dari hasil evaluasi yang dilakukan dapat dilihat pada Tabel 2.

Tabel 2.Hasil Evaluasi Wawasan Warga Sekolah Lab. Undiksha tentang Sekolah Berwawasan Lingkungan dan Mitigasi Bencana (SWALIBA)

\begin{tabular}{|c|c|c|c|c|c|c|c|c|c|}
\hline \multirow{3}{*}{ No. } & \multirow{3}{*}{ Kriteria } & \multicolumn{8}{|c|}{ Wawasan tentang SWALIBA dari } \\
\hline & & \multicolumn{2}{|c|}{ Pengelola } & \multicolumn{2}{|c|}{ Guru } & \multicolumn{2}{|c|}{ Pegawai } & \multicolumn{2}{|c|}{ Total } \\
\hline & & $\mathbf{N}$ & $\%$ & $\mathbf{N}$ & $\%$ & $\mathbf{N}$ & $\%$ & $\mathbf{N}$ & $\%$ \\
\hline 1. & Sangat Baik & 3 & 37,50 & 8 & 6,66 & 11 & 28,95 & 22 & 13,25 \\
\hline 2. & Baik & 5 & 62,50 & 102 & 85,00 & 27 & 71,05 & 134 & 80,73 \\
\hline 3. & Cukup & - & - & 5 & 4,17 & - & - & 5 & 3,01 \\
\hline 4. & Kurang & - & - & 5 & 4,17 & - & - & 5 & 3,01 \\
\hline \multirow[t]{2}{*}{5.} & Sangat Kurang & - & & & & - & - & & \\
\hline & Total & 8 & 100,00 & 120 & 100,00 & 38 & 100,00 & 166 & 100,00 \\
\hline
\end{tabular}

Sumber: Hasil Pengolahan Data Primer 
Tabel 2 menunjukkan bahwa sosialisasi Program SWALIBA untuk warga Sekolah Lab. Undiksha telah memberikan wawasan tentang SWALIBA. Lebih dari $90 \%$ warga Sekolah Lab. Undiksha memperoleh skor dalam katagori baik dan sangat baik. Hanya sebagian kecil yang memperoleh skor dengan kategori cukup dan kurang.

Walaupun secara persentase relatif kecil $(<5 \%)$, namun penting dilakukan penelusuran lebih jauh sehingga dapat dipamahami penyebabnya. Jika memperhatikan masing-masing item yang ada dalam alat evaluasi yang digunakan, pertanyaan/pernyataan yang berkontribusi pada perolehan skor kurang baik ditemukan pada tiga (3) pertanyaan/pernyataan, yaitu: berkenaan dengan Pendidikan Kependudukan dan Lingkungan Hidup (PKLH) yang disamakan dengan Pendidikan Lingkungan sebagai upaya penanaman budaya melestarikan lingkungan, (2) berkenaan dengan tahapan dalam pasca bencana, dan (3) berkenaan dengan tahapan pelaksanaan SWALIBA (Organizing, Motivating, dan Coordinating) yang sebenarnya sebagai suatu kesatuan.

Rendahnya skor yang diperoleh pada ke tiga pertanyaan/pernyataan tersebut untuk peserta yang terkategori baik (skor $=70$ ) ada dua kemungkinan, yaitu: (1) ketidak cermatan dalam membaca pertanyaan/pernyataan tersebut karena keterbatasan waktu yang diberikan, dan (2) peserta yang bersangkutan memang belum memahami hal tersebut. Sementara jika memperhatikan peserta yang memperoleh skor terkategori cukup $($ skor $=60)$ dan kurang (skor $=50$ ), kecenderungannya adalah yang kedua yang terjadi, yaitu peserta bersangkutan memang belum memahami SWALIBA dengan baik.

Terlepas dari peserta yang memperoleh skor cukup dan kurang, jika mengacu pada hasil evaluasi yang diperoleh dapat dikemukakan bahwa metode pendidikan yang diimplementasikan dalam kegiatan PkM ini yang dilakukan melalui webinar telah mampu mengembangkan wawasan warga Sekolah Lab. Undiksha tentang SWALIBA. Hal ini tentu akan memudahkan jalan ke depan untuk mengembangkan Program SWALIBA Sekolah Lab. Undiksha. Program yang baik akan dapat disusun jika melibatkan keterwakilan seluruh komponen yang ada di dalam instansi/organisasi yang bersangkutan.

Selain itu, hal yang dinilai positif dari respon yang diberikan adalah kesiapan Pengelola, Guru, dan Pegawai untuk memberikan dukungan terhadap Program SWALIBA Sekolah Lab. Undiksha. Respon itu diberikan oleh seluruh peserta sosialisasi, baik pengelola, guru, maupun pegawai. Warga Sekolah Lab. Undiksha dalam hal ini telah menyadari bahwa kebutuhan masyarakat Indonesia saat ini adalah menciptakan manusia yang tidak hanya berperilaku arif terhadap lingkungan, akan tetapi juga penciptaan insan-insan yang bisa hidup berdampingan dengan bencana. Berkenaan dengan itu peranan sekolah sebagai suatu wadah pendidikan merupakan strategi yang dinilai memiliki kemampuan untuk menerapkan hal tersebut.

Hal ini merupakan langkah awal yang baik untuk pencanangan Program SWALIBA di Sekolah Lab. Undiksha sebagai bentuk Pendidikan Karakter sehingga Sekolah Lab. Undiksha dapat menjadi tempat untuk menstimulasi siswa agar menjadi insan-insan yang berwawasan lingkungan dan mitigasi bencana di bawah bimbingan dan pengawasan guru. Sekolah Lab. Undiksha dalam hal ini akan menjadi tempat yang signifikan bagi siswa yang masih berada dalam tahap perkembangan dan juga akan menjadi sebuah lingkungan social yang berpengaruh bagi kehidupan siswa dalam mengembangkan karakter berwawasan lingkungan dan mitigasi bencana. Jadi dengan demikian, penanaman kepedulian terhadap kelestarian sumberdaya alam dan lingkungan dilingkungan sekolah serta tanggap bencana jika telah dilakukan 
sejak dini maka diharapkan akan terbentuk rasa menghargai, memiliki, dan memelihara sumberdaya alam dan tanggap terhadap bencana pada diri masing-masing siswa.

\section{KESIMPULAN}

Wawasan SWALIBA warga Sekolah Lab. Undiksha yang ratarata tergolong baik $(74,73)$ merupakan awal yang baik dalam rangka pengembangan Program SWALIBA di Sekolah Lab. Undiksha. Pemahaman yang baik warga Sekolah Lab. Undiksha tentang SWALIBA akan dapat memberikan masukan yang komprehensif pada saat penyusunan Program SWALIBA di Sekolah Lab. Undiksha. Selain itu, dengan pemahaman yang baik ini diharapkan dapat diikuti dengan perilaku berwawasan lingkungan dan mitigasi bencana dari warga Sekolah Lab. Undiksha sehingga dapat dijadikan panutan oleh siswa pada saat program SWALIBA diimplementasikan di Sekolah Lab. Undiksha.

\section{DAFTAR PUSTAKA}

Bali

Post, 2017.

https://www.balipost.com/news /2017/12/20/32014/Tiga-

Patahan-Ditemukan,Buleleng-

Rawan...html. Diakses Tgl. 11 April 2021.

Dhaniaputri, Risanti. 2017. Ilmu Botani sebagai Dasar Keanekaragaman Jenis Tumbuhan dalam Pelestarian Lingkungan. Prosiding disampaikan dalam Seminar Nasional Pendidikan Sains (SNPS) 2017 dengan Tema "Strategi Pengembangan Pembelajaran dan Penelitian Sains untuk Mengasah Keterampilan Abad 21 (Creativity and Innovation, Critical Thinking and Problem Solving, Communication, Collaboration/4C) " Universitas Sebelas Maret Surakarta, 26 Oktober 2017.
Iswari, R.D \& Utomo, S.W. (2017). Evaluasi Penerapan Program Adiwiyata Untuk Membentuk Perilaku Peduli Lingkungan di Kalangan Siswa. Jurnal IImu Lingkungan. Vol. 15 (1): 35-41.

Kesuma, Dharma, dkk. 2012. Pendidikan Karakter Kajian Teori dan Praktik di Sekolah. Bandung: PT Remaja Rosdakarya.

Mahbubi, M. 2012. Pendidikan Karakter Implementasi Aswaja sebagai Nilai Pendidikan Karakter. Yogyakarta: Pustaka IImu.

Nusa Bali, 2020. https://www.nusabali.com/ber ita/75388/ahli-geologiingatkan-potensi-tsunami-diseririt. Diakses Tgl. 11 April 2021.

Peraturan Pemerintah Republik Indonesia Nomor 21 Tahun 2008 tentang

Penyelenggaraan

Penanggulangan Bencana. Diundangkan Di Jakarta, Pada Tanggal 28 Februari 2008

Undang-Undang Republik Indonesia Nomor 24 Tahun 2007 tentang Penanggulangan Bencana. Diundangkan di Jakarta Pada tanggal 26 April 2007

Undang-Undang Nomor 32 Tahun 2009 tentang Pengelolaan Lingkungan Hidup

Windawati, Ary, Setyowati, Dewi Liesnoor. 2015. Evaluasi Program Sekolah Hijau (Green School) di SMA Negeri 7 Purworejo sebagai Persiapan Menuju Rintisan Swaliba (Sekolah Berwawasan Lingkungan dan Mitigasi Bencana) dimuat dalam Edu Geography 3 (7) (2015). 